\title{
Nanolayered Double Hydroxide Inhibits the Pathogenicity of Vibrio parahaemolyticus
}

\author{
Cang Wang $\mathbb{D}^{1,2}$ Xiaoyi Ma, ${ }^{1,2}$ Jie Hu, ${ }^{1,2}$ Xiaopeng Tian, ${ }^{1,2}$ Hao Zhang, ${ }^{1,2}$ Dongxue Dong, ${ }^{1,2}$ \\ Zaixi Fang, ${ }^{1,2}$ Mingsheng Lyu, ${ }^{1,2}$ Shujun Wang $\mathbb{D}^{1,2}$ and Jing $\mathrm{Lu} \mathbb{1}^{1,2}$ \\ ${ }^{1}$ Jiangsu Key Laboratory of Marine Bioresources and Environment/Jiangsu Key Laboratory of Marine Biotechnology, \\ Jiangsu Ocean University, Lianyungang 222005, China \\ ${ }^{2}$ Co-Innovation Center of Jiangsu Marine Bio-Industry Technology, Jiangsu Ocean University, Lianyungang 222005, China
}

Correspondence should be addressed to Shujun Wang; sjwang@jou.edu.cn and Jing Lu; jinglu@jou.edu.cn

Received 23 July 2021; Revised 22 September 2021; Accepted 11 October 2021; Published 16 November 2021

Academic Editor: Haisheng Qian

Copyright ( 2021 Cang Wang et al. This is an open access article distributed under the Creative Commons Attribution License, which permits unrestricted use, distribution, and reproduction in any medium, provided the original work is properly cited.

\begin{abstract}
Nanolayered double hydroxide (LDH) is a type of anion layered inorganic compound whose bacteriostatic properties have recently garnered much attention. Vibrio parahaemolyticus is a marine pathogen that can lead to aquaculture diseases and substantial economic losses. Therefore, our study assessed the mechanisms by which $\mathrm{Mg} / \mathrm{Al}-\mathrm{LDH}$ prevents $V$. parahaemolyticus infection. Our results demonstrated that $\mathrm{Mg} / \mathrm{Al}-\mathrm{LDH}$ not only inhibited $V$. parahaemolyticus growth but also biofilm formation. Moreover, coupling $\mathrm{Mg} / \mathrm{Al}-\mathrm{LDH}$ with hydrogen peroxide and $\mathrm{UV}$ irradiation further inhibited the growth and biofilm formation of $V$. parahaemolyticus. Additionally, Mg/Al-LDH was found to adversely affect DNA and the gelling ability of chitosan. Furthermore, exposing $V$. parahaemolyticus to Mg/Al-LDH led to a $54.73 \%$ and $4.3 \%$ inhibition in the expression of the toxic genes $t h$ and $t r h$, respectively. $\mathrm{Mg} / \mathrm{Al}-\mathrm{LDH}$ also improved the symptoms of $V$. parahaemolyticus infection in Penaeus vannamei, making this a promising candidate to prevent pathogenic bacteria infection in aquaculture.
\end{abstract}

\section{Introduction}

Nanolayered double hydroxide (LDH), also known as anionic clay [1], is a type of anionic layered compound consisting of a positively charged metal hydroxide outlayer and a negative anion interlayer [2]. The molecular formula of $\mathrm{LDH}$ is $\left[\mathrm{M}^{\mathrm{II}}{ }_{1-x} \mathrm{M}^{\mathrm{III}}{ }_{x}(\mathrm{OH})_{2}\right]^{x+}\left(\mathrm{A}^{n-}\right)_{\mathrm{X} / n} \cdot y \mathrm{H}_{2} \mathrm{O}$ $(x=0.2-0.33, y=0.5-1)$, where $\mathrm{M}^{\mathrm{III}}$ represents trivalent metal ions, $\mathrm{M}^{\mathrm{II}}$ represents divalent metal ions, $\mathrm{A}^{n-}$ represents $n$-valent anions, and LDH represents the different structures that can be synthesized by changing the value of $x[3,4]$. $\mathrm{LDH}$ can be cost-effectively prepared in the laboratory with good biocompatibility, adjustable layer charge density and particle size, low storage requirements, and low toxicity [1, 5]. LDH with various unique properties can be synthesized through different combinations of divalent metal ions and trivalent metal ions, as well as changes in proportion $[1,6]$. LDH has many unique characteristics, including the adjust- ability of laminate element composition, exchangeability of the negative anion interlayer, thermal stability, $\mathrm{pH}$ sensitivity, and memory, all of which make this material uniquely well suited for a variety of applications in several fields such as biomedicine [7-9], adsorption [10-12], catalysis [13-15], and environmental remediation [16-18].

Particularly, the antibacterial properties of LDH have garnered much attention in recent years. Ding et al. [19] assessed LDH toxicity in Chlorophyta and found that this compound was highly toxic to Streptococcus, with an $\mathrm{EC}_{50}$ of $10 \mathrm{mg} / \mathrm{L}$ after $72 \mathrm{~h}$ of LDH exposure. Further, Streptococcus growth was completely inhibited when the LDH concentration reached $50 \mathrm{mg} / \mathrm{L}$. An $\mathrm{LDH}$ prepared by Moaty et al. exhibited long-lasting antibacterial activity against Gramnegative bacteria (Proteus vulgaris, Klebsiella pneumoniae, Escherichia coli, and Pseudomonas aeruginosa) and Grampositive bacteria (Staphylococcus epidermidis, Staphylococcus aureus, Aspergillus, Streptococcus pyogenes, and Salmonella) 
[20]. Many studies have also confirmed that LDH has a good bacteriostatic effect when combined with other compounds or materials [21-25].

$V$. parahaemolyticus was first discovered by Tsunesaburo Fujino of Osaka University after a seafood poisoning outbreak in Japan in 1950 [26]. V. parahaemolyticus is a Gram-negative halophilic bacterium that is commonly found in estuaries and marine environments and various types of seafood [27], which can cause aquaculture diseases and considerable economic losses to the aquaculture industry. Moreover, people who consume raw or undercooked seafood are at high risk of becoming infected with $V$. parahaemolyticus. The symptoms of $V$. parahaemolyticus infection include diarrhea that lasts for 2 to 10 days, abdominal cramps, nausea, vomiting, and headaches [28]. Wound infection with $V$. parahaemolyticus can also lead to septicemia, which can be fatal [29-31]. Marine animals such as bony fish and grouper, mud crabs, and shrimp infected with $V$. parahaemolyticus often exhibit marked histopathological changes and increased mortality, thus resulting in huge economic losses to the aquaculture industry [32-34].

Several studies have evaluated the virulence factors and pathogenesis of $V$. parahaemolyticus. One such study found that the pathogenicity of $V$. parahaemolyticus was closely related to many virulence factors, including hemolysin, type III secretion system, type VI secretion system, adhesion factor, and iron uptake system [28, 35]. It has also been reported that $V$. parahaemolyticus produces three kinds of hemolysin: thermally stable direct hemolysin $(t d h)$, tdhassociated hemolysin (trh), and heat-intolerant hemolysin $(t h)$, which are encoded by the $t d h$, trh, and $t$ lh genes, respectively [36, 37]. Additionally, V. parahaemolyticus often forms biofilms and becomes embedded in its own extracellular polymeric matrix, making this pathogen uniquely resistant to cleaning and disinfection processes [38-40]. Therefore, biofilms protect microbial communities and facilitate quorum sensing.

Our study investigated the effects of exposed $\mathrm{Mg} / \mathrm{Al}$ $\mathrm{LDH}$ on $V$. parahaemolyticus when the Mg/Al-LDH and $V$. parahaemolyticus were exposed together. Furthermore, the mechanisms of effects were explored. The purpose is to reduce the chance of humans and aquaculture being infected with $V$. parahaemolyticus. Our findings indicated that $\mathrm{Mg} /$ Al-LDH prevented $V$. parahaemolyticus in Penaeus vanna$m e i$, thus highlighting the promising potential of $\mathrm{Mg} / \mathrm{Al}$ $\mathrm{LDH}$ as an antibacterial agent to increase aquaculture yields.

\section{Materials and Methods}

2.1. Materials and Strains. A V. parahaemolyticus strain was purchased from the China Industrial Microbial Culture Collection and Management Center (CICC 10552, ATCC17802, ATCC33846). Mg/Al-LDH was synthesized in the laboratory. TSB medium: tryptone $15 \mathrm{~g}$, soybean peptone $5 \mathrm{~g}, \mathrm{NaCl}$ $30 \mathrm{~g}$, deionized water $1 \mathrm{~L}, \mathrm{pH} 7.0 \sim 7.4$; autoclaved at $121^{\circ} \mathrm{C}$ and $0.15 \mathrm{MPa}$ for $20 \mathrm{~min}$. 2216E medium: $1 \mathrm{~g}$ yeast powder, $5 \mathrm{~g}$ fish meal peptone, $\mathrm{pH} 7.4$, seawater $1 \mathrm{~L}$. Nutrient broth medium $(3 \% \mathrm{NaCl})$ : peptone $10 \mathrm{~g}$ beef extract $3 \mathrm{~g}, \mathrm{NaCl}$ $30 \mathrm{~g}, \mathrm{pH}$ 7.0. All reagents were of analytical grade.
Table 1: Primer sequences.

\begin{tabular}{lc}
\hline Primer & Sequence $\left(5^{\prime}-3^{\prime}\right)$ \\
\hline Tdh-F & GCT GCA TTC AAA ACA TCT GC TT \\
Tdh-R & CTC GAA CAA ACA ATA TCT CAT CA \\
Trh-F & GAG GAC TAT TGG ACA AAC CGA AA \\
Trh-R & TGT CAT ATA GGC GCT TAA CCA CTT \\
Tlh-F & CCA ACC TTA TCA CCA GAA \\
Tlh-R & ATA CCA ACA GCG AAC ATA \\
PvsA-F & CTC CTT CAT CCA ACA CGA T \\
PvsA-R & GGG CGA GAT AAT CCT TGT \\
PvuA-F & CAA ACT CAC TCA GAC TC \\
PvuA-R & CGA ACC GAT TCA ACA C \\
\hline
\end{tabular}

2.2. Effect of $\mathrm{Mg} / \mathrm{Al}-\mathrm{LDH}$ on $\mathrm{V}$. parahaemolyticus Growth. V. parahaemolyticus was inoculated into TSB broth containing different $\mathrm{Mg} / \mathrm{Al}-\mathrm{LDH}$ concentrations $(0-100 \mathrm{mg} / \mathrm{L})$. The strain was incubated at $30^{\circ} \mathrm{C}$ and $180 \mathrm{r} / \mathrm{min}$ for $24 \mathrm{~h}$, and the optical density at $600 \mathrm{~nm}$ was detected in a 96-well plate using a microplate reader (Infinite M1000 Pro, Tecan, Switzerland).

2.3. Effect of Mg/Al-LDH When Coupled with UV Irradiation or Hydrogen Peroxide. The activated V. parahaemolyticus was inoculated into media containing $\mathrm{Mg} / \mathrm{Al}-\mathrm{LDH}$ $(100 \mathrm{mg} / \mathrm{L})$ and then irradiated with ultraviolet light for 0 $300 \mathrm{~s}$. The strain was also grown without $\mathrm{Mg} / \mathrm{Al}-\mathrm{LDH}$ as a control treatment. Similarly, different concentrations of hydrogen peroxide $(0-500 \mathrm{mM})$ were added to the growth media containing $\mathrm{Mg} / \mathrm{Al}-\mathrm{LDH}(100 \mathrm{mg} / \mathrm{L})$, after which $\mathrm{OD}_{600}$ of the broth was measured.

2.4. Effect of $\mathrm{Mg} / \mathrm{Al}-\mathrm{LDH}$ on $\mathrm{V}$. parahaemolyticus Biofilm Formation. $V$. parahaemolyticus biofilm formation was assessed as described by Yin et al. [40] with slight modifications. Specifically, this study explored the effect of $\mathrm{Mg} / \mathrm{Al}-$ $\mathrm{LDH}$ on the biofilm formation of $V$. parahaemolyticus. The activated $V$. parahaemolyticus $(50 \mu \mathrm{L})$, fresh medium, and $\mathrm{Mg} / \mathrm{Al}-\mathrm{LDH}$ were mixed in microplates to a $250 \mu \mathrm{L}$ total volume. The final concentrations of $\mathrm{Mg} / \mathrm{Al}-\mathrm{LDH}$ were 0 $100 \mathrm{mg} / \mathrm{L}$. Then, the microplates were incubated at $30^{\circ} \mathrm{C}$ for $24 \mathrm{~h}$. Afterward, the medium was removed and the wells were washed three times with $250 \mu \mathrm{L}$ of phosphate-buffered saline (PBS). The microplates were then dried in a $60^{\circ} \mathrm{C}$ oven for $1 \mathrm{~h}$. The biofilms were stained with $250 \mu \mathrm{L}$ of $0.1 \%$ crystal violet solution at room temperature for $15 \mathrm{~min}$. After gently washing the samples with PBS to remove excess crystal violet, the stained biofilm was dried again. Afterward, $250 \mu \mathrm{L}$ of glacial acetic acid (30\%) was added to dissolve the crystal violet stain and the optical density was measured at $590 \mathrm{~nm}$.

Next, V. parahaemolyticus $(50 \mu \mathrm{L})$, fresh medium, Mg/ Al-LDH $(100 \mathrm{mg} / \mathrm{L})$, and hydrogen peroxide were mixed in microplates to a $250 \mu \mathrm{L}$ total volume. The final hydrogen peroxide concentration ranged between 0 and $500 \mathrm{mM}$. A blank control was prepared without Mg/Al-LDH. Biofilm formation was detected after incubation. 


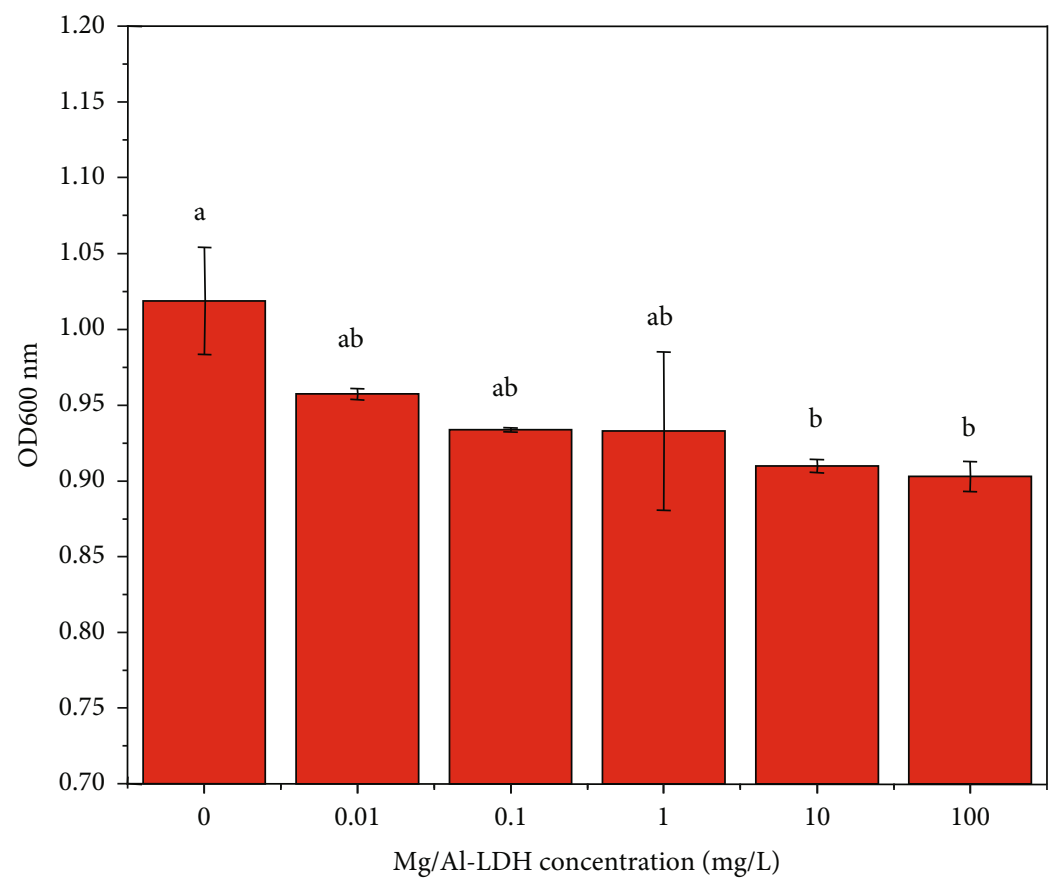

(a)

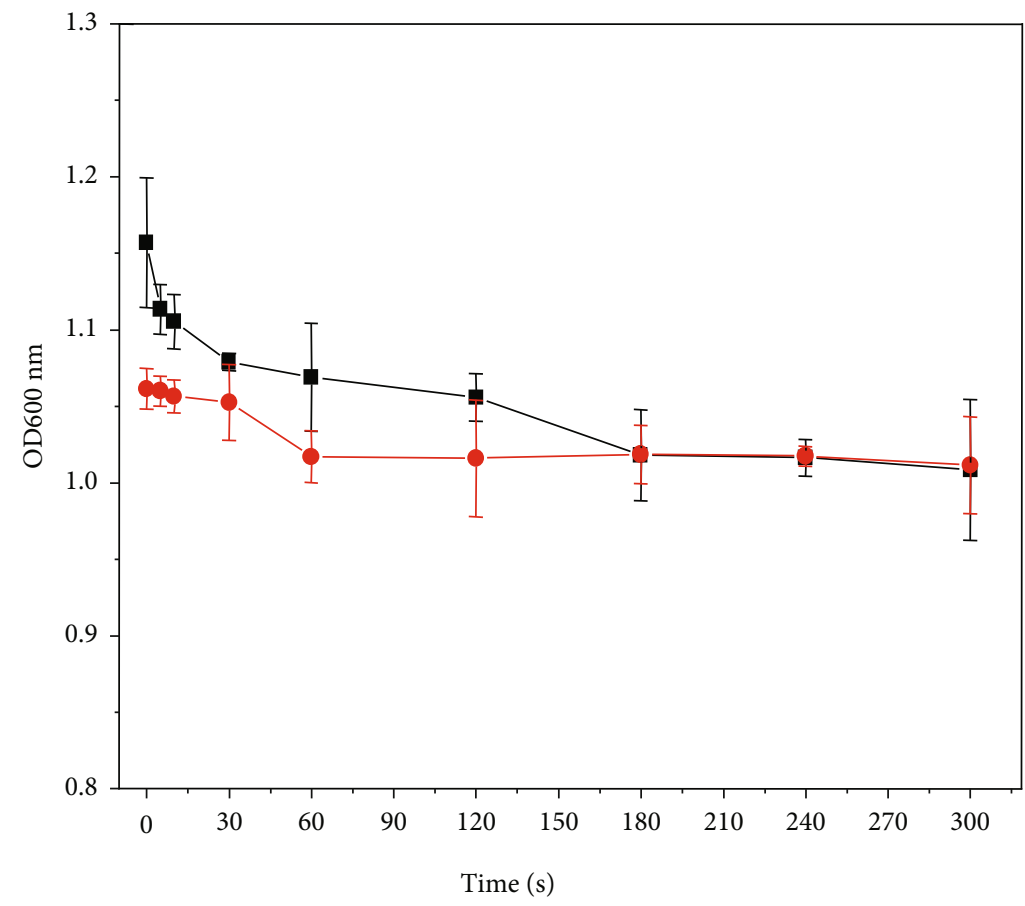

- - Control

- $100 \mathrm{mg} / \mathrm{L} \mathrm{Mg} / \mathrm{Al}-\mathrm{LDH}$

(b)

Figure 1: Continued. 


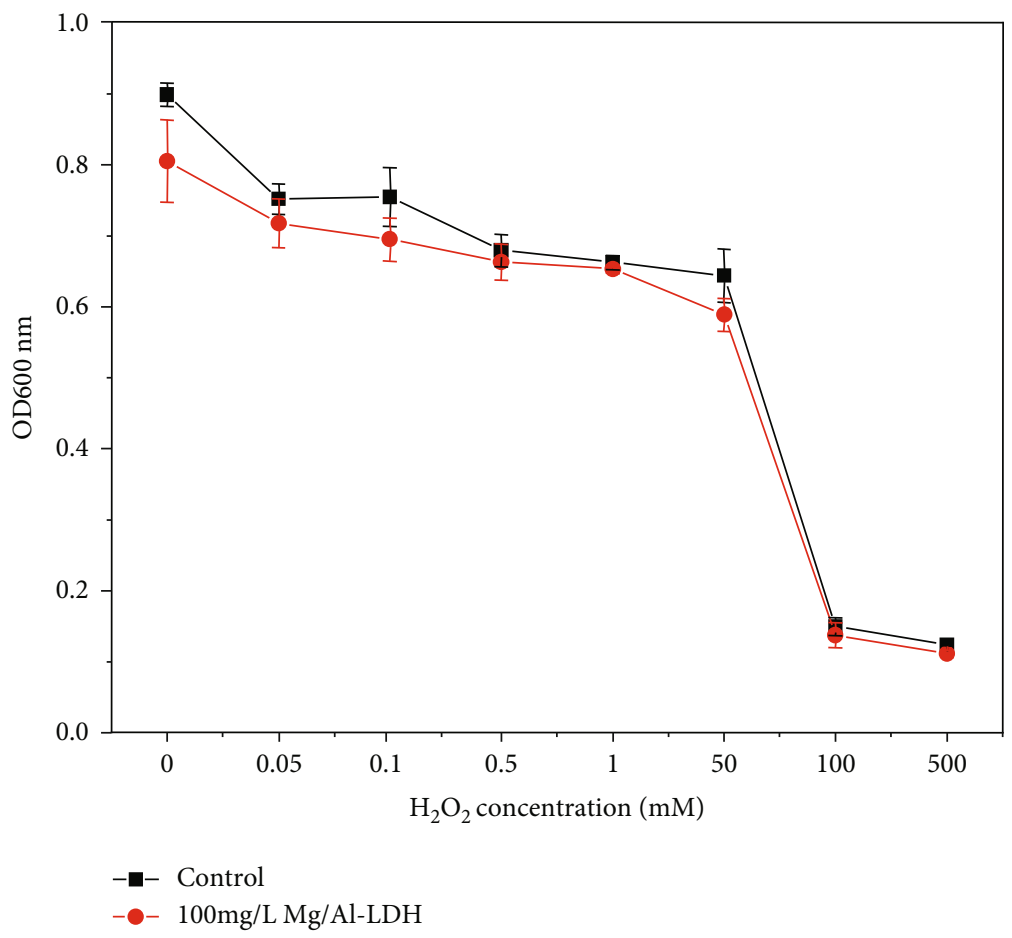

(c)

FIgURE 1: Effect of (a) Mg/Al-LDH concentration, (b) UV irradiation, and (c) hydrogen peroxide concentration on $V$. parahaemolyticus growth.

Finally, $V$. parahaemolyticus $(50 \mu \mathrm{L})$, fresh medium, $\mathrm{Mg} /$ $\mathrm{Al}-\mathrm{LDH}(100 \mathrm{mg} / \mathrm{L})$, and hydrogen peroxide $(50 \mathrm{mM})$ were mixed in microplates to a $250 \mu \mathrm{L}$ total volume and then irradiated with ultraviolet light for 0-300 s. A blank control was prepared without $\mathrm{Mg} / \mathrm{Al}-\mathrm{LDH}$. Biofilm formation was detected after incubation.

2.5. Effects of Mg/Al-LDH on Polysaccharides. Chitosan and $2.5 \%$ glutaraldehyde form a gel after being placed in a water bath at $70^{\circ} \mathrm{C}$ for $1 \mathrm{~h}$. We then added $200 \mu \mathrm{L}$ of $0.5 \%$ chitosan solution, $20 \mu \mathrm{L}$ of $2.5 \%$ glutaraldehyde, and $\mathrm{Mg} / \mathrm{Al}-\mathrm{LDH}$ $(100 \mathrm{mg} / \mathrm{L})$ to glass bottles to a final $250 \mu \mathrm{L}$ volume, after which they were treated with hydrogen peroxide $(50 \mathrm{mM})$ and UV irradiation $(2 \mathrm{~min})$. The samples were taken out of the water bath $\left(70^{\circ} \mathrm{C}\right)$ after $1 \mathrm{~h}$. Upon gel formation, the weight of the gel was measured.

2.6. Effects of $\mathrm{Mg} / \mathrm{Al}-\mathrm{LDH}$ on Proteins. Bovine serum protein (BSA) is a typical functional protein. A $250 \mu \mathrm{L}$ system was prepared by mixing $\mathrm{Mg} / \mathrm{Al}-\mathrm{LDH}(100 \mathrm{mg} / \mathrm{L})$, bovine serum protein, followed by hydrogen peroxide $(50 \mathrm{mM})$ or UV irradiation (2 min). SDS-PAGE gel electrophoresis and quantitative analysis were then performed after incubation for $2 \mathrm{~h}$ in a $37^{\circ} \mathrm{C}$ water bath.

2.7. Effects of $M g / A l-L D H$ on DNA Integrity. Salmon DNA was added to a $50 \mu \mathrm{L}$ system with $\mathrm{Mg} / \mathrm{Al}-\mathrm{LDH}(100 \mathrm{mg} / \mathrm{L})$, hydrogen peroxide $(50 \mathrm{mM})$, or UV irradiation $(2 \mathrm{~min})$ and then incubated in a $37^{\circ} \mathrm{C}$ water bath for $2 \mathrm{~h}$. Afterward, $1 \%$ agar electrophoresis was conducted for verification and quantitative analysis was performed using a microanalyzer.

2.8. Effect of $\mathrm{Mg} / \mathrm{Al}-\mathrm{LDH}$ on $\mathrm{V}$. parahaemolyticus Toxicity Genes. SYBR staining was used to quantify the relative expression of toxicity genes using an internal reference. $V$. parahaemolyticus ATCC33846 (2216E medium, $\left.30^{\circ} \mathrm{C}\right)$ and $V$. parahaemolyticus ATCC17802 $(3 \% \mathrm{NaCl}$ nutrient gravy medium, $37^{\circ} \mathrm{C}$ ) were incubated at $180 \mathrm{r} / \mathrm{min}$ for $12 \mathrm{~h}$. The $V$. parahaemolyticus strains exposed to $\mathrm{Mg} / \mathrm{Al}-\mathrm{LDH}$ $(100 \mathrm{mg} / \mathrm{L})$ were then continually cultured. DNA was extracted separately for later use. The expression of the toxic genes trh, $t d h$, and th of $V$. parahaemolyticus in response to $\mathrm{Mg} / \mathrm{Al}-\mathrm{LDH}$ exposure was detected via fluorescence quantitative PCR and compared to that of unexposed bacteria. The primer sequences are shown in Table 1 . The reactions were conducted in $20 \mu \mathrm{L}$ volumes ( $2 x$ ChamQ SYBR qPCR Master Mix $(10 \mu \mathrm{L})$, forward primer $(10 \mu \mathrm{M} ; 0.8 \mu \mathrm{L})$, reverse primer $(10 \mu \mathrm{M} ; 0.8 \mu \mathrm{L}), 50 x$ ROX Reference Dye $(0.4 \mu \mathrm{L})$, DNA $\left.(4 \mu \mathrm{L}), \mathrm{ddH}_{2} \mathrm{O}(4 \mu \mathrm{L})\right)$.

2.9. P. vannamei Infection Experiments. Healthy white shrimp ( $P$. vannamei; $6 \mathrm{~cm}$ long) were purchased from the Lianyungang Wholesale Market. Twelve $P$. vannamei were placed in each water tank outfitted with a circulating filter device to maintain water quality. The water temperature and salinity of the water tank were controlled to $25^{\circ} \mathrm{Cand}$ $20 \%$, respectively. Once the shrimp were adapted to the growth environment, $20 \mathrm{~mL}$ of $V$. parahaemolyticus (ATCC17802; $1.21 \times 108 \mathrm{CFU} / \mathrm{mL}$ ) was added to 


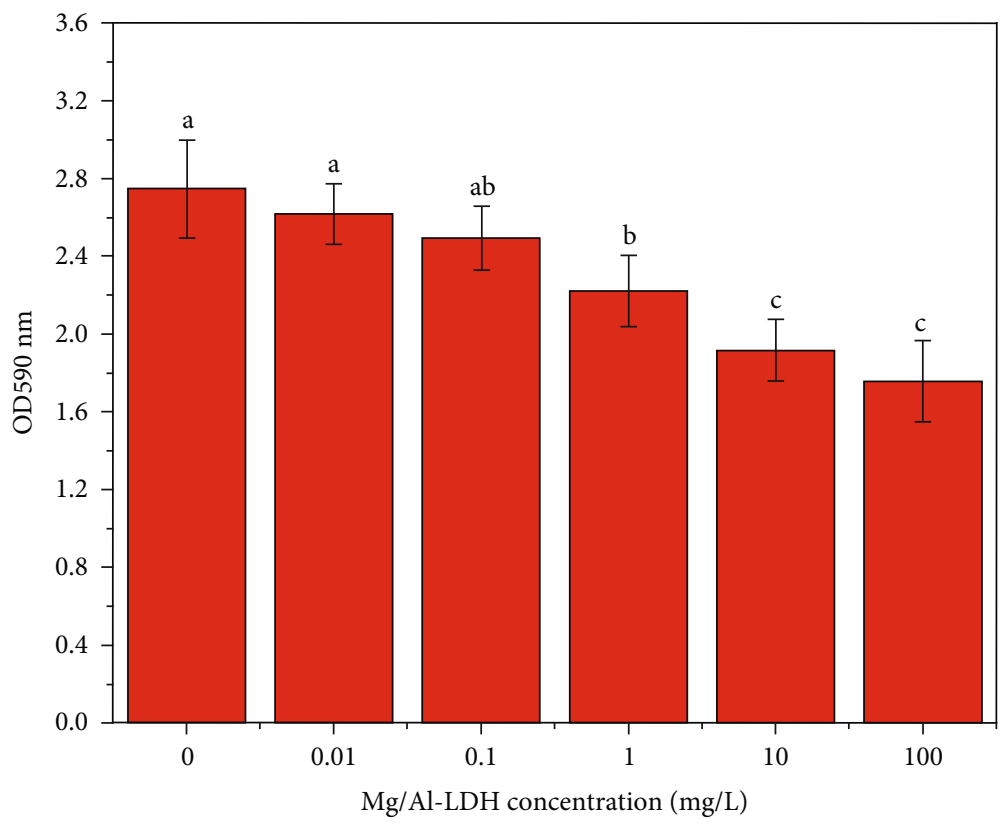

(a)

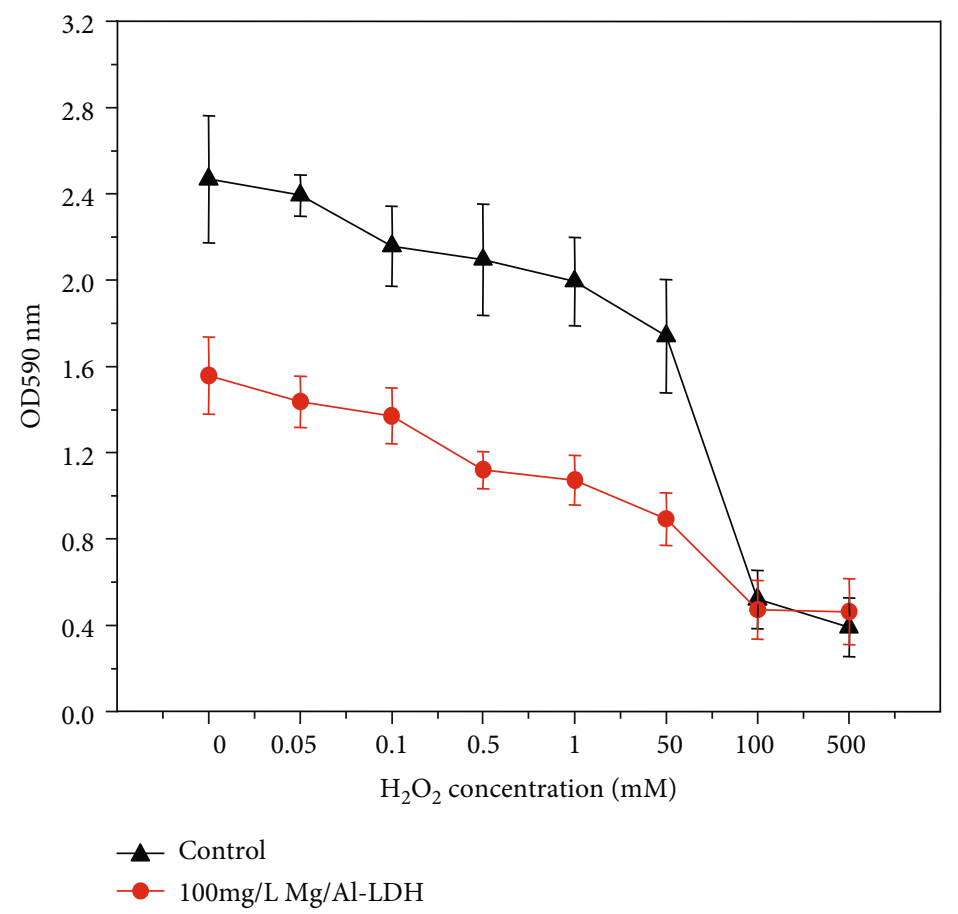

(b)

Figure 2: Continued. 


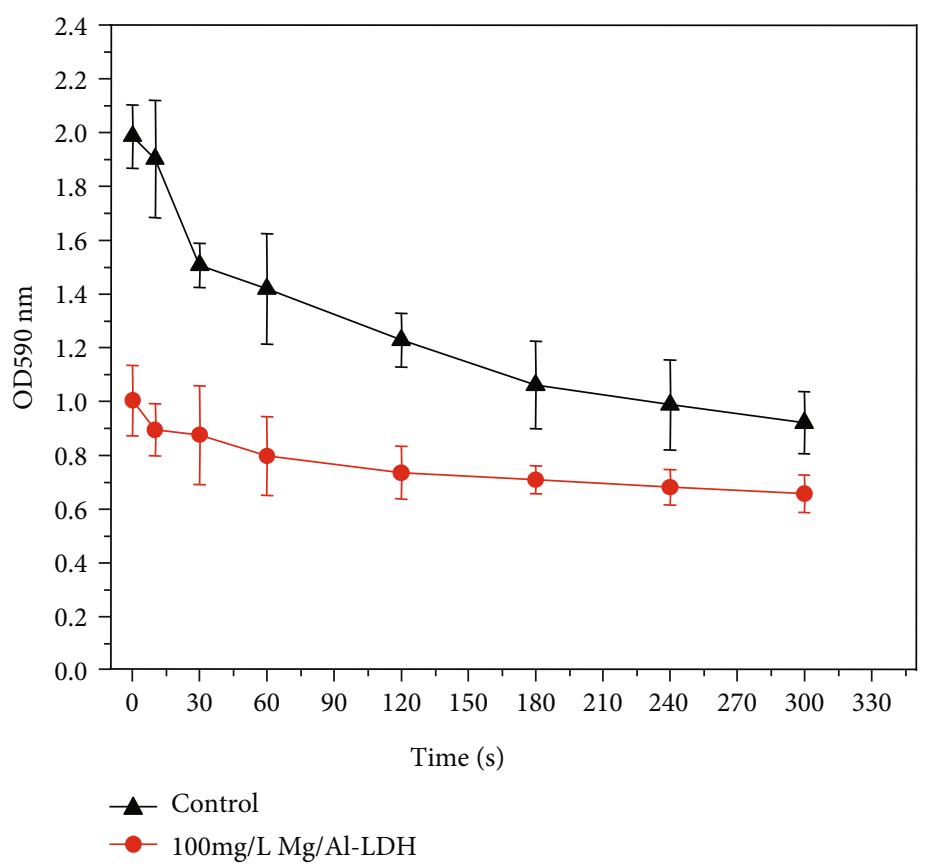

(c)

FIgURE 2: Effects of (a) Mg/Al-LDH concentration, (b) hydrogen peroxide concentration, and (c) UV irradiation time on $V$. parahaemolyticus biofilm formation.

experimental groups 1 and 2. Afterward, $100 \mathrm{mg} / \mathrm{mL}$ of $\mathrm{Mg} /$ $\mathrm{Al}-\mathrm{LDH}$ was added to experimental group 2. The control was neither infected with $V$. parahaemolyticus nor treated with $\mathrm{Mg} / \mathrm{Al}-\mathrm{LDH}$. The shrimp were fed once every $24 \mathrm{~h}$; infection progression and mortality were monitored every day.

2.10. Statistical Analysis. All experiments were conducted in triplicate, from which means and standard deviations were calculated. Significance was conducted using the S-N-K(S) test in SPSS.

\section{Results and Discussion}

\subsection{Results}

3.1.1. Effect of Mg/Al-LDH on V. parahaemolyticus Growth. $\mathrm{Mg} / \mathrm{Al}-\mathrm{LDH}$ significantly inhibited $V$. parahaemolyticus growth at a $100 \mathrm{mg} / \mathrm{L}$ concentration (Figure $1(\mathrm{a})$ ), with OD values reaching only $90 \%$ compared to the control. The growth of $V$. parahaemolyticus treated with $\mathrm{Mg} / \mathrm{Al}-\mathrm{LDH}$ was more severely inhibited within a short time of UV irradiation (Figure 1(b)). However, once the irradiation time reached $2 \mathrm{~min}$, the growth inhibition of $V$. parahaemolyticus was largely unaffected by $\mathrm{Mg} / \mathrm{Al}-\mathrm{LDH}$. Combining hydrogen peroxide with $\mathrm{Mg} / \mathrm{Al}-\mathrm{LDH}$ had a stronger inhibitory effect on the growth of the strain. Particularly, hydrogen peroxide concentrations ranging from 0 to $50 \mathrm{mM}$ effectively inhibited the growth of $V$. parahaemolyticus when coupled with $\mathrm{Mg} / \mathrm{Al}-\mathrm{LDH}$ (100 mg/L) (Figure 1(c)). However, when the concentration of hydrogen peroxide reached $100 \mathrm{mM}$, the turbidity of the bacterial liquid was lower than 0.2. At this point, bacterial growth was mainly inhibited by hydrogen peroxide. Therefore, $\mathrm{Mg} / \mathrm{Al}-\mathrm{LDH}(100 \mathrm{mg} / \mathrm{L})$ inhibited $V$. parahaemolyticus growth most efficiently when combined with low concentrations of hydrogen peroxide.

3.1.2. Effect of $\mathrm{Mg} / \mathrm{Al}-\mathrm{LDH}$ on $\mathrm{V}$. parahaemolyticus Biofilm Formation. We next assessed the effect of Mg/Al-LDH on the formation of $V$. parahaemolyticus biofilm. With increasing $\mathrm{Mg} / \mathrm{Al}-\mathrm{LDH}$ concentrations, $V$. parahaemolyticus biofilm formation was gradually inhibited (Figure 2(a)). The results showed that $\mathrm{OD}_{590}$ decreased from 2.75 to 1.76 and the inhibition rate reached $36 \%$.

$V$. parahaemolyticus biofilms were severely damaged during the formation process (Figure 2(b)). As the concentration of hydrogen peroxide increased, the biofilm of the experimental group was more severely damaged. However, when the concentration of hydrogen peroxide reached $100 \mathrm{mM}$, the growth of $V$. parahaemolyticus was severely inhibited and biofilm formation was reduced. At this point, $\mathrm{Mg} / \mathrm{Al}-\mathrm{LDH}$ had little effect on $V$. parahaemolyticus biofilm formation. However, when the concentration of hydrogen peroxide was $50 \mathrm{mM}$, the growth of $V$. parahaemolyticus was not severely inhibited. The results showed that $\mathrm{OD}_{590}$ of the control group was 1.74 and $\mathrm{OD}_{590}$ of the experimental group treated with $\mathrm{Mg} / \mathrm{Al}-\mathrm{LDH}$ was 0.89 .

The effects of UV irradiation coupled with hydrogen peroxide and $\mathrm{Mg} / \mathrm{Al}-\mathrm{LDH}$ on $V$. parahaemolyticus biofilm formation in microplates were also assessed. V. parahaemolyticus biofilm formation was more severely inhibited when all three factors were combined. Our results demonstrated that $\mathrm{OD}_{590}$ of the control group decreased from 1.99 to 0.92 , indicating that the biofilm formation could be inhibited 

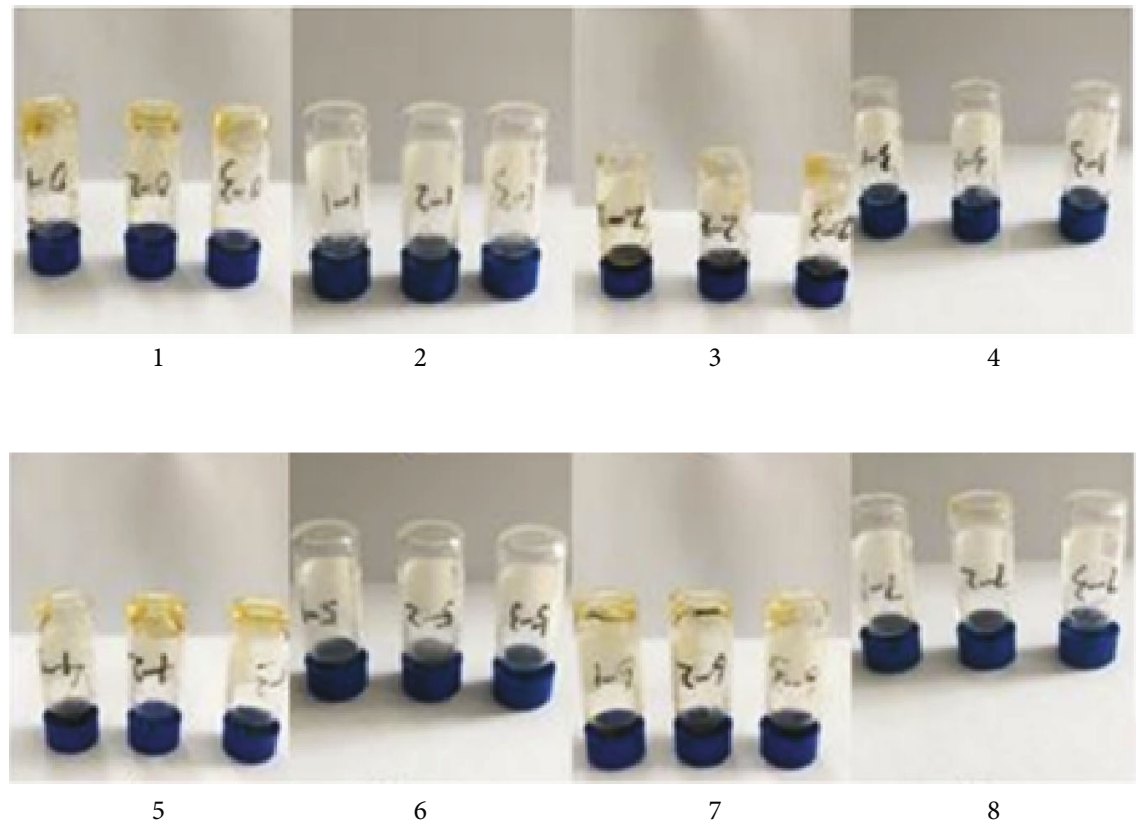

(a)

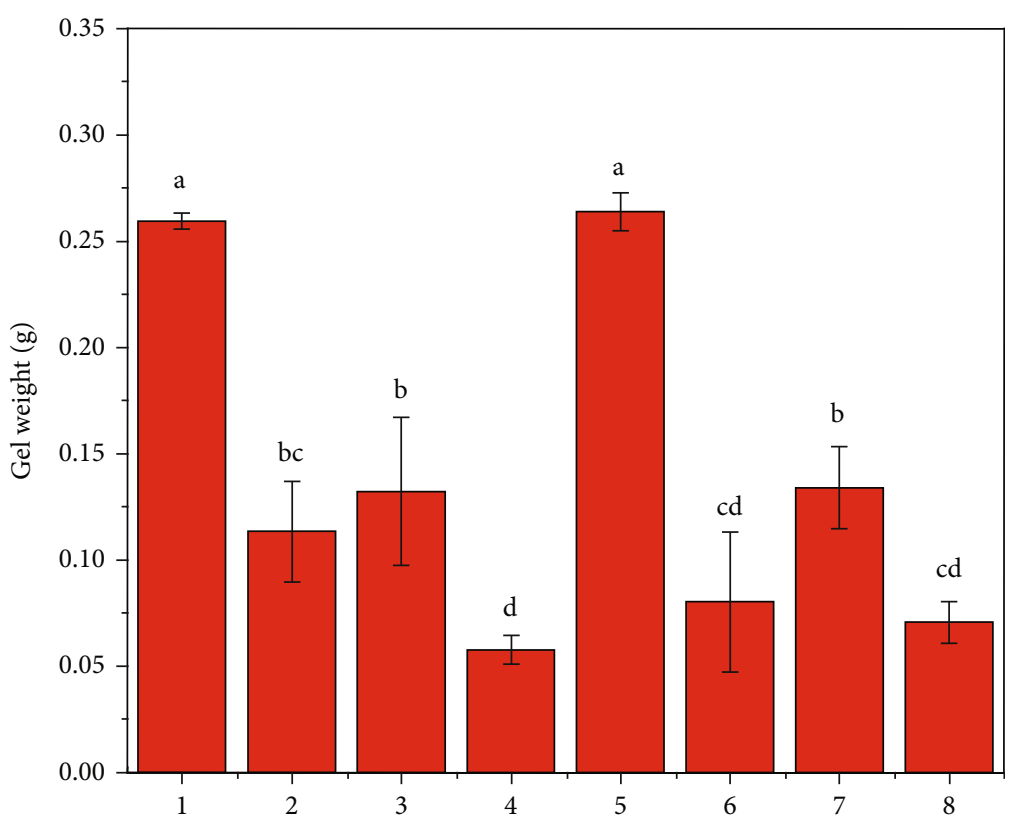

(b)

Figure 3: Continued. 


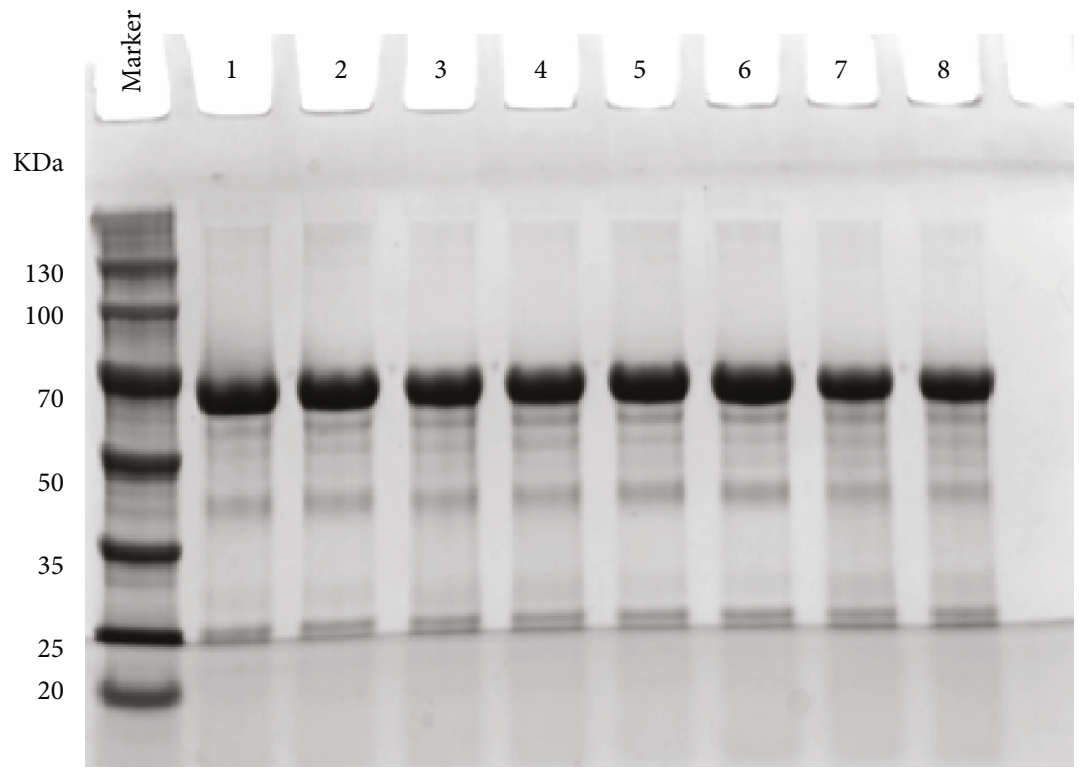

(c)

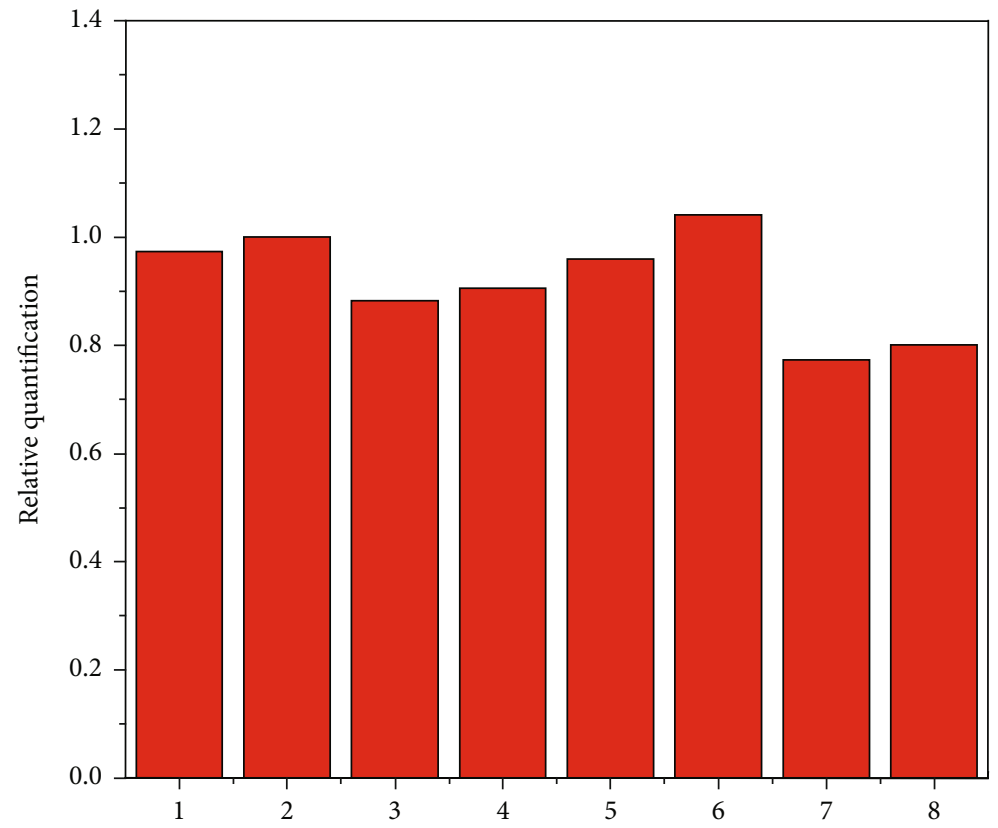

(d)

FIGURE 3: (a) Affection on polysaccharide gel and (b) weight analysis of the polysaccharide gels. The numbers in (a) and (b) indicate (1) chitosan, (2) chitosan $+\mathrm{LDH},(3)$ chitosan $+\mathrm{H}_{2} \mathrm{O}_{2}$, (4) chitosan $+\mathrm{H}_{2} \mathrm{O}_{2}+\mathrm{LDH}$, (5) chitosan $+\mathrm{UV},(6)$ chitosan $+\mathrm{LDH}+\mathrm{UV},(7)$ chitosan $+\mathrm{H}_{2} \mathrm{O}_{2}$ $+\mathrm{UV}$, and (8) chitosan+LDH $+\mathrm{H}_{2} \mathrm{O}_{2}+\mathrm{UV}$. (c) SDS-PAGE gel electrophoresis of bovine serum albumin after 2 hours in a water bath. (d) Quantitative analysis of the relative quality of the SDS-PAGE BSA electrophoresis. The numbers in (c) and (d) represent (1) BSA, (2) $\mathrm{BSA}+\mathrm{LDH}$, (3) $\mathrm{BSA}+\mathrm{H}_{2} \mathrm{O}_{2}$, (4) $\mathrm{BSA}+\mathrm{H}_{2} \mathrm{O}_{2}+\mathrm{LDH}$, (5) $\mathrm{BSA}+\mathrm{UV}$, (6) $\mathrm{BSA}+\mathrm{LDH}+\mathrm{UV}$, (7) $\mathrm{BSA}+\mathrm{H}_{2} \mathrm{O}_{2}+\mathrm{UV}$, and (8) $\mathrm{BSA}+\mathrm{LDH}+\mathrm{H}_{2} \mathrm{O}_{2}+\mathrm{UV}$.

by UV irradiation and the inhibition increased with increasing irradiation time (Figure 2(c)). In the experimental group, $\mathrm{OD}_{590}$ decreased from 1.01 to 0.66 .

3.1.3. Effects of $M g / A l-L D H$ on Polysaccharides. Chitosan and glutaraldehyde undergo a gelling reaction when heated to $70^{\circ} \mathrm{C}$. However, upon adding $\mathrm{Mg} / \mathrm{Al}-\mathrm{LDH}(100 \mathrm{mg} / \mathrm{L})$, the gelling reaction is greatly reduced. This indicated that $\mathrm{Mg} / \mathrm{Al}-\mathrm{LDH}$ can inhibit the gelation ability of polysaccharides. Moreover, polysaccharides were further weakened when treated with $\mathrm{Mg} / \mathrm{Al}-\mathrm{LDH}$, hydrogen peroxide, and UV light (Figure 3(b)).

3.1.4. Effect of $M g / A l-L D H$ on Protein. Based on the comparisons between 1 and 2, 3 and 4, 5 and 6 , and 7 and 8 in Figure $3(\mathrm{~d})$, the protein residue in the experimental group with $\mathrm{Mg} / \mathrm{Al}-\mathrm{LDH}$ was slightly higher than that without $\mathrm{Mg} / \mathrm{Al}-\mathrm{LDH}$. However, as illustrated by the comparison between 2 and 8 , the most significant protein degradation 


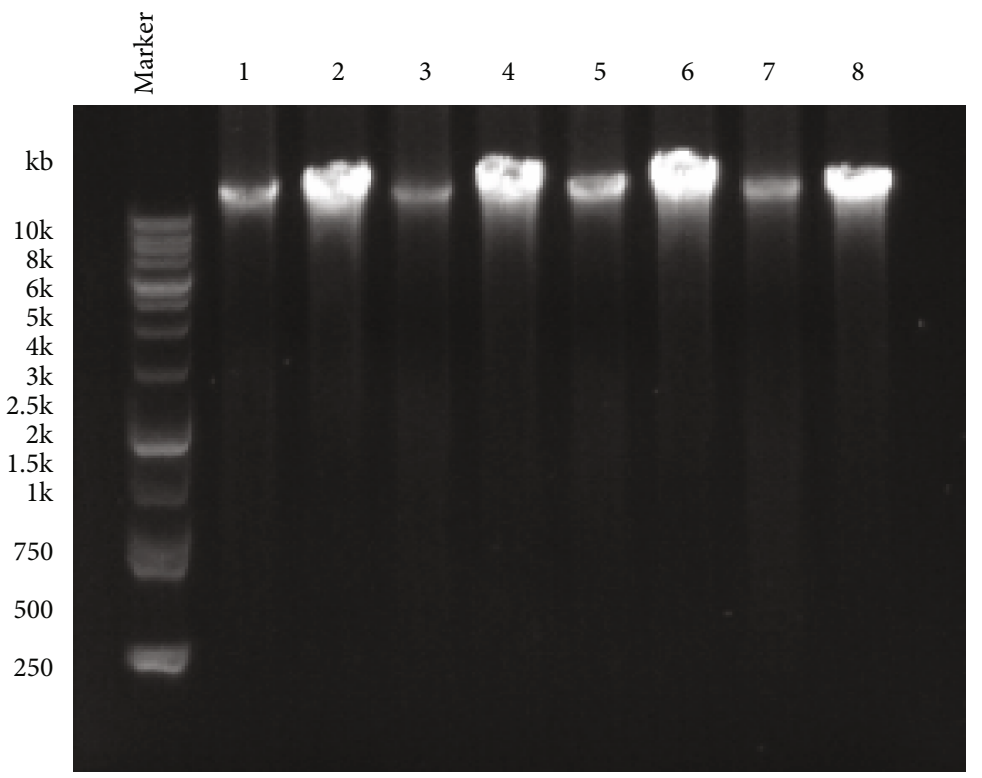

(a)

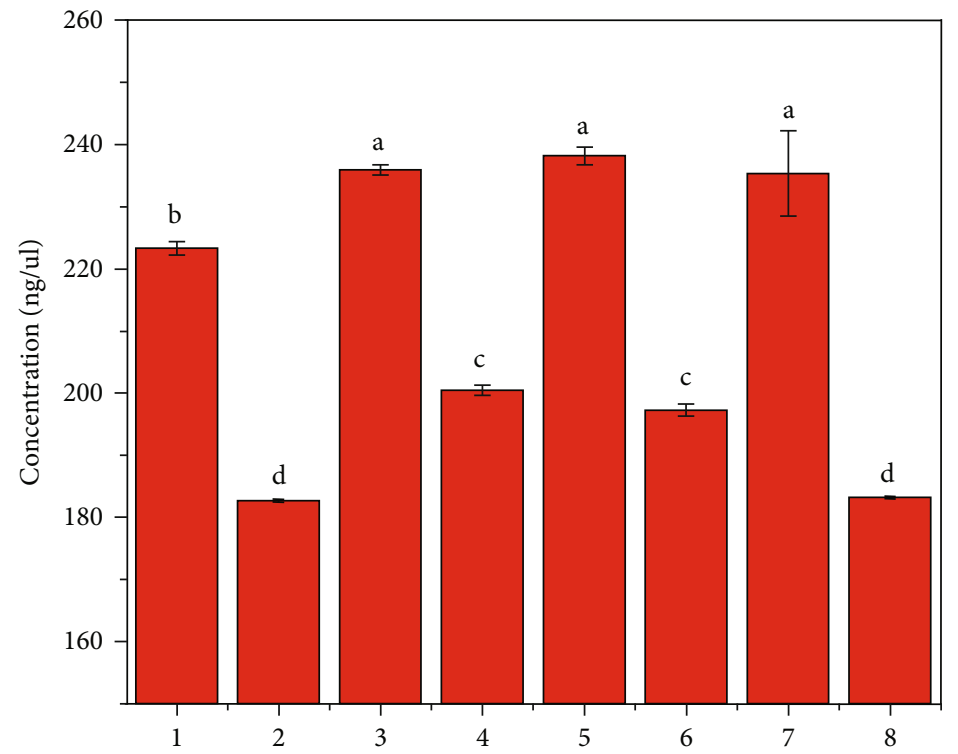

(b)

Figure 4: Continued. 


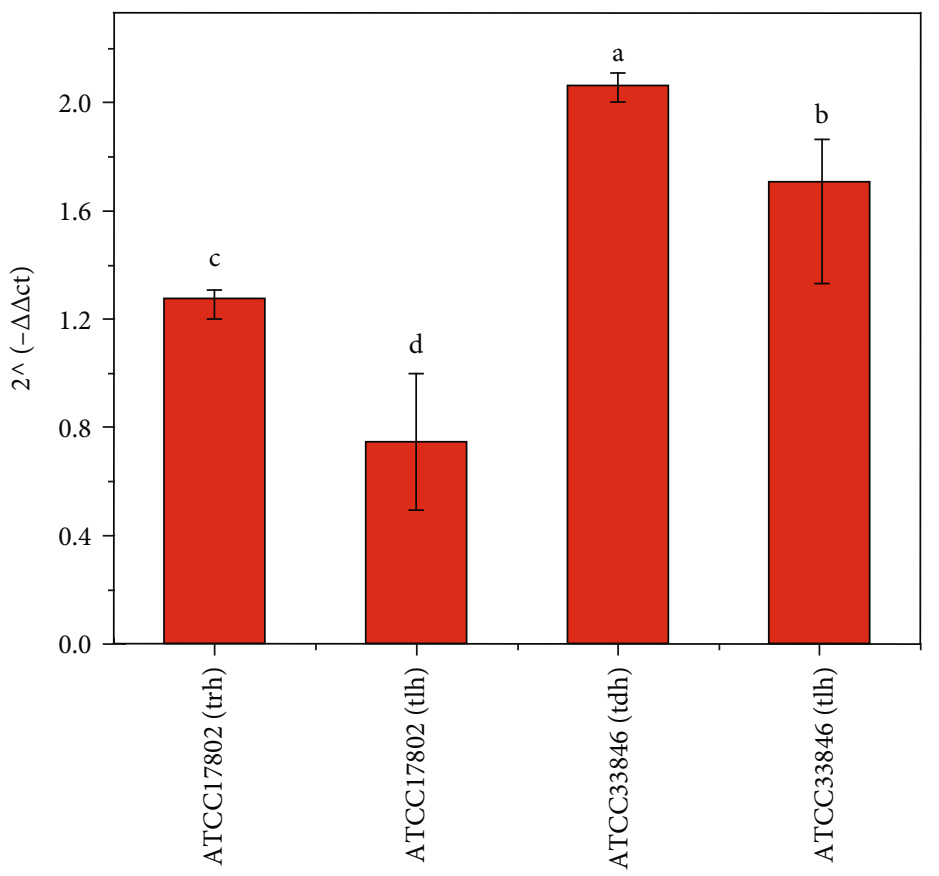

(c)

Figure 4: (a) Agarose gel electrophoresis after DNA water bath for 2 hours. (b) Quantitative analysis of DNA with a microanalyzer. The numbers in (a) and (b) represent (1) DNA, (2) DNA+LDH, (3) DNA+ $\mathrm{H}_{2} \mathrm{O}_{2}$, (4) DNA $+\mathrm{H}_{2} \mathrm{O}_{2}+\mathrm{LDH}$, (5) DNA+UV, (6) DNA+LDH+UV, (7) $\mathrm{DNA}+\mathrm{H}_{2} \mathrm{O}_{2}+\mathrm{UV}$, and (8) DNA+LDH $+\mathrm{H}_{2} \mathrm{O}_{2}+\mathrm{UV}$. (c) Effects of $\mathrm{Mg} / \mathrm{Al}-\mathrm{LDH}$ on the expression of $V$. parahaemolyticus virulence genes.

effect was obtained when $\mathrm{Mg} / \mathrm{Al}-\mathrm{LDH}$, hydrogen peroxide, and ultraviolet light were combined.

3.1.5. Effect of $M g / A l-L D H$ on DNA. Our study also explored whether DNA is degraded under $\mathrm{Mg} / \mathrm{Al}-\mathrm{LDH}$, hydrogen peroxide, and ultraviolet conditions. To achieve this, DNA, $\mathrm{Mg} / \mathrm{Al}-\mathrm{LDH}$, and hydrogen peroxide were mixed, irradiated with UV rays, and incubated in a $37^{\circ} \mathrm{C}$ water bath for $2 \mathrm{~h}$. After subsequent quantitative analysis using a microanalyzer, the values of $1,3,5$, and 7 were all higher than those of 2, 4, 6, and 8 (Figure 4(b)). This indicated that $\mathrm{Mg} / \mathrm{Al}$ LDH addition caused DNA degradation.

3.1.6. Effect of $M g / A l-L D H$ on the Expression of ToxicityAssociated Genes in $V$. parahaemolyticus. The extracted DNA was quantitatively analyzed via fluorescence quantitative PCR. As shown in Figure 4(c), Mg/Al-LDH exerted $4.3 \%$ and $54.73 \%$ inhibition rates for the trh and th genes of strain ATCC17802. In contrast, $\mathrm{Mg} / \mathrm{Al}-\mathrm{LDH}$ promoted the expressions of the $t d h$ and $t$ th genes by $60.21 \%$ and $35.19 \%$ in the ATCC33846 strain.

3.1.7. Infection Experiment. The shrimps (P. vannamei) were placed in each water tank outfitted with a circulating filter (Figure 5(a)). After breeding for a period of time under different conditions, as illustrated in Figures 5(b) and 5(c), the symptoms of $P$. vannamei upon $V$. parahaemolyticus infection in experimental group 1 were more severe than those in experimental group 2. The shrimp in experimental group 2 did not appear sluggish but presented hepatopancreas ulcers and hyperemia. Ulcers were not detected in the parotid glands, tail fans, appendages, and swimming appendages. Additionally, as illustrated in Figure 5(d), shrimp mortality in experimental group 2 was much lower than that in experimental group 1 after 3-11 days of infection.

3.2. Discussion. $\mathrm{Mg} / \mathrm{Al}-\mathrm{LDH}$ significantly inhibited $V$. parahaemolyticus growth that was consistent with the excellent antibacterial properties of $\mathrm{Zn} / \mathrm{Fe}-\mathrm{LDH}$ reported by Moaty et al. on several common bacteria such as Pseudomonas aeruginosa and Staphylococcus aureus [20]. Previous studies have shown that LDHs had a strong inhibitory effect on the growth of some pathogenic bacteria and might therefore be used to treat and prevent bacterial infection. Ultraviolet (UV) light, an important component of Earth's natural lighting, kills microorganisms by changing and damaging the structure of their DNA [41]. Particularly, UVC can effectively kill bacteria, viruses, protists, and other microorganisms [42] and is therefore often used as a disinfectant. Within a short time of UV irradiation, the growth of $V$. parahaemolyticus treated with $\mathrm{Mg} / \mathrm{Al}-\mathrm{LDH}$ was more severely inhibited. This may have been because short-term UVC irradiation destroyed the DNA of V.parahaemolyticus, thereby inhibiting its growth. The decomposition of hydrogen peroxide can produce free radicals, which can inactivate microorganisms by interfering with cell membranes, DNA, and proteins $[43,44]$. Therefore, combining hydrogen peroxide with $\mathrm{Mg} / \mathrm{Al}-\mathrm{LDH}$ had a stronger inhibitory effect on the growth of the strain.

Biofilms are composed of a variety of biological macromolecules such as proteins, polysaccharides, DNA, RNA, 


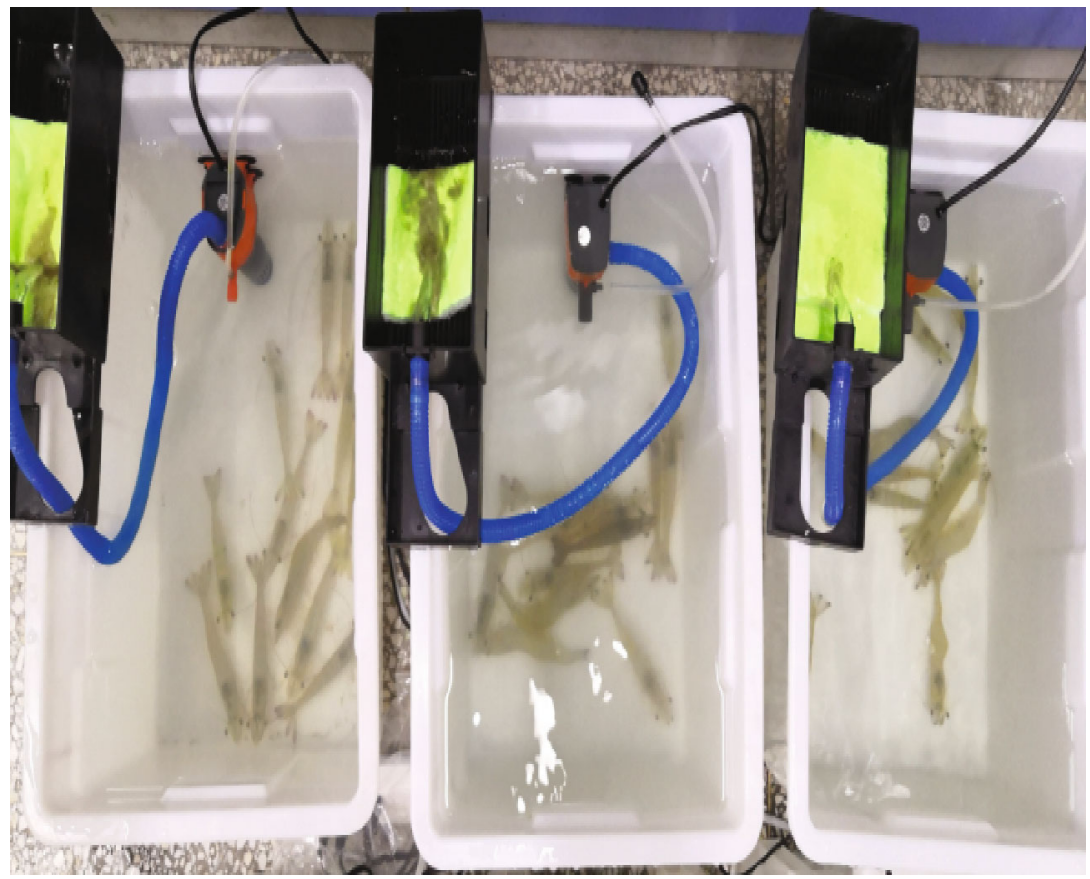

(a)

\begin{tabular}{|c|c|c|c|}
\hline $\begin{array}{c}\text { Symptoms of } \\
\text { infection }\end{array}$ & Control & $\begin{array}{c}\text { Experimental } \\
\text { group } 1\end{array}$ & $\begin{array}{l}\text { Experimental } \\
\text { group } 2\end{array}$ \\
\hline $\begin{array}{c}\text { Hepatopancreas } \\
\text { fester and } \\
\text { hyperemia }\end{array}$ & - & ++ & - \\
\hline $\begin{array}{l}\text { Parotid gland } \\
\text { fester and } \\
\text { hyperemia }\end{array}$ & - & ++ & + \\
\hline $\begin{array}{c}\text { Tail fan fester and } \\
\text { hyperemia }\end{array}$ & - & ++ & + \\
\hline $\begin{array}{l}\text { Appendages, } \\
\text { swimming feet } \\
\text { fester and } \\
\text { hyperemia }\end{array}$ & - & ++ & + \\
\hline $\begin{array}{l}\text { Whole body } \\
\text { hyperemia }\end{array}$ & - & + & - \\
\hline Sluggish action & - & ++ & - \\
\hline Deaths & 0 & 12 & 7 \\
\hline
\end{tabular}

(b)

Figure 5: Continued. 


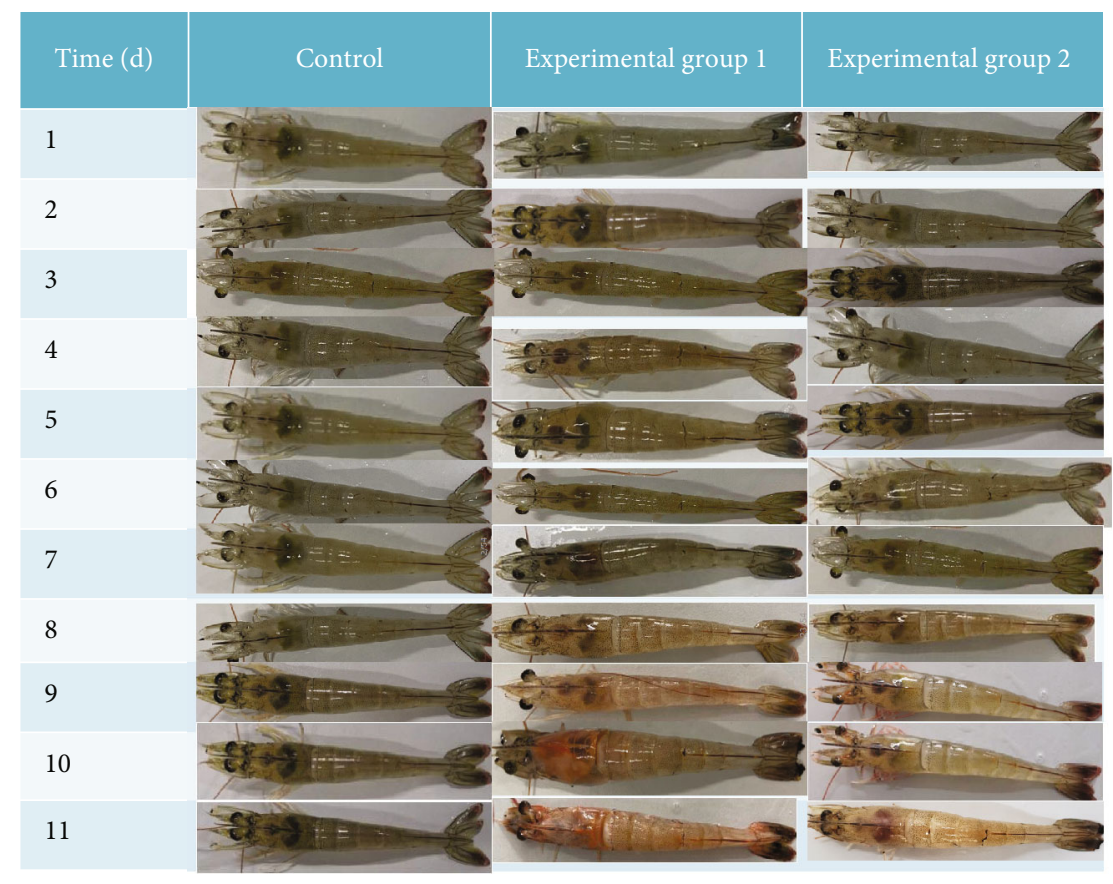

(c)

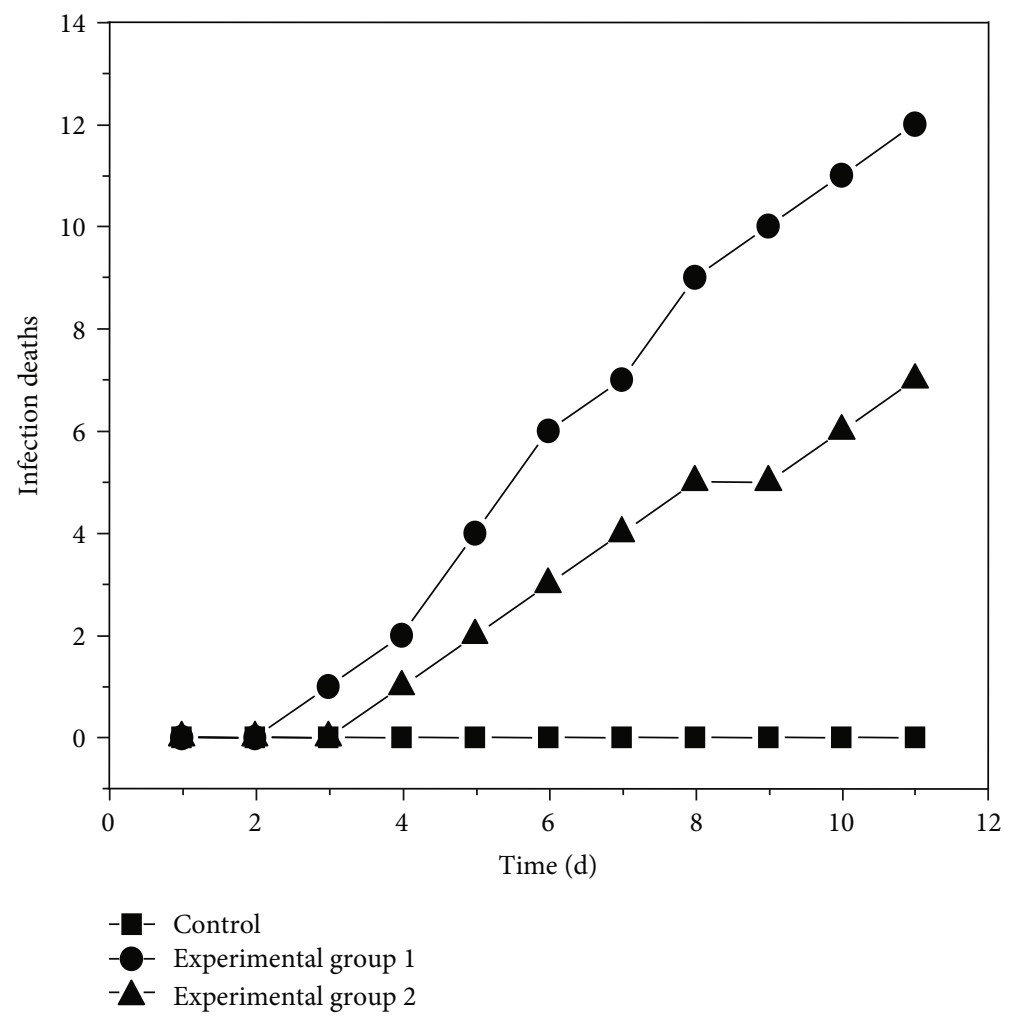

(d)

FIgURE 5: (a) Experimental environment. (b) Evaluation of infection symptoms. (c) Impact of different treatments on Penaeus vannamei. (d) Mortality rates upon infection. Experimental group 1: V. parahaemolyticus. Experimental group 2: V. parahaemolyticus and Mg/Al-LDH.

peptidoglycans, lipids, and phospholipids. These complex matrices render bacteria highly resistant to antibiotics, as well as cleaning and disinfection processes [40]. Adding $\mathrm{Mg} / \mathrm{Al}-\mathrm{LDH}$ could effectively inhibit the formation of bio- films that might be because $\mathrm{Mg} / \mathrm{Al}-\mathrm{LDH}$ destroys major macromolecules such as polysaccharides and DNA during biofilm formation. And hydrogen peroxide, $\mathrm{Mg} / \mathrm{Al}-\mathrm{LDH}$, and UV irradiation could inhibit the formation of $V$. 
parahaemolyticus biofilm more effectively, in which hydrogen peroxide and ultraviolet radiation can destroy the biofilm to varying degrees.

Chitosan is a natural polysaccharide derived from chitin. It is the second most ubiquitous naturally occurring polysaccharide after cellulose. Chitosan is obtained when chitin is deacetylated to approximately $50 \%$ of free amines. As a biopolymer, chitosan has attracted much attention due to its biomedical applications [45]. In our study, Mg/Al-LDH can inhibit the gelation ability of polysaccharides. This might be because $\mathrm{Mg} / \mathrm{Al}-\mathrm{LDH}$ was adsorbed on the polysaccharide, thus affecting its gelling ability.

Bovine serum albumin (BSA), a typical functional protein molecule, is cost-efficient, safe, degradable, rich in chemical groups, and relatively stable, all of which make this protein uniquely well suited for medical care and pharmaceutical applications [46]. Our research results showed that $\mathrm{Mg} / \mathrm{Al}-\mathrm{LDH}$ did not degrade bovine serum proteins. Therefore, we speculated that $\mathrm{Mg} / \mathrm{Al}-\mathrm{LDH}$ may not disrupt most proteins in cells. In many reports, $\mathrm{LDH}$ is used for drug delivery [47]. $\mathrm{Mg} / \mathrm{Al}-\mathrm{LDH}$ was likely adsorbed on the protein, thus preventing its degradation.

Deoxyribonucleic acid (DNA) is a kind of polynucleotide that carries essential genetic information and can be used to encode messenger RNA and proteins. DNA has been widely used in gene therapy, biosensing, and information storage. But $\mathrm{Mg} / \mathrm{Al}-\mathrm{LDH}$ could degrade salmon DNA. Therefore, $\mathrm{Mg} / \mathrm{Al}-\mathrm{LDH}$ may damage the DNA of $V$. parahaemolyticus, which provides an important basis for the further exploration of the molecular mechanisms of $\mathrm{Mg} / \mathrm{Al}-$ LDH-mediated antibacterial effects. The results of subsequent toxic gene experiments were also consistent with these observations. It was confirmed that $\mathrm{Mg} / \mathrm{Al}-\mathrm{LDH}$ can inhibit the expression of virulence-associated genes in some $V$. parahaemolyticus strains. Therefore, our findings indicated that $\mathrm{Mg} / \mathrm{Al}-\mathrm{LDH}$ not only inhibits the growth of $V$. parahaemolyticus but also downregulates the expression of toxic genes.

Shrimp mortality in experimental group 2 was much lower than that in experimental group 1 after infection. These observations were consistent with our previous results, thus confirming that $\mathrm{Mg} / \mathrm{Al}-\mathrm{LDH}$ can inhibit the pathogenicity of $V$. parahaemolyticus. This was mainly due to the cytotoxicity of $\mathrm{Mg} / \mathrm{Al}-\mathrm{LDH}$ to $V$. parahaemolyticus, which disrupts its biofilm and affects the expression of toxic genes. Ahmed et al. [48] reported that the effect of nanoparticles (NPs) on bacteria mainly depends on certain mechanisms, including the interaction with cell barriers, penetration through diffusion and adsorption, inhibition of bacterial proteins and DNA synthesis, regulation of metabolic gene expression, and inhibition of biofilm formation.

\section{Conclusions}

LDH, a novel low-toxicity nanomaterial, plays an important role in various industries. In this study, this nanomaterial was used to prevent and control bacterial infection in Pacific white leg shrimp (i.e., a widely cultured aquaculture species).

The following are the key conclusions of this study:
(1) $\mathrm{Mg} / \mathrm{Al}-\mathrm{LDH}$ had a certain inhibitory effect on the growth of $V$. parahaemolyticus, which could be enhanced when coupled with hydrogen peroxide and UV irradiation

(2) $\mathrm{Mg} / \mathrm{Al}-\mathrm{LDH}$ also effectively inhibited V. parahaemolyticus biofilm formation. However, the addition of hydrogen peroxide and UV radiation did not significantly enhance the inhibitory effects of $\mathrm{Mg} / \mathrm{Al}-\mathrm{LDH}$ on $V$. parahaemolyticus biofilm formation

(3) $\mathrm{Mg} / \mathrm{Al}-\mathrm{LDH}$ inhibited the chitosan gelling reaction, and this effect was further enhanced by hydrogen peroxide addition. Moreover, $\mathrm{Mg} / \mathrm{Al}-\mathrm{LDH}$ had a weak protective effect on bovine serum protein. $\mathrm{Mg} / \mathrm{Al}-\mathrm{LDH}$ also caused considerable DNA damage

(4) $\mathrm{Mg} / \mathrm{Al}-\mathrm{LDH}$ inhibited the expression of the trh and th genes of strain ATCC17802 by $4.3 \%$ and $54.73 \%$, respectively

(5) Our infection experiments indicated that the addition of $\mathrm{Mg} / \mathrm{Al}-\mathrm{LDH}$ could reduce Penaeus vannamei mortality caused by $V$. parahaemolyticus infection

These five conclusions confirm the important role of $\mathrm{Mg} / \mathrm{Al}-\mathrm{LDH}$ in the prevention and treatment of $V$. parahaemolyticus. Therefore, our study provides a robust basis for the development of novel strategies to protect human health and control bacterial diseases in the seafood industry.

\section{Data Availability}

The data used to support the findings of this study are included within the article.

\section{Conflicts of Interest}

All authors have declared that (i) no support, financial or otherwise, has been received from any organization that may have an interest in the submitted work and (ii) there are no other relationships or activities that could appear to have influenced the submitted work.

\section{Authors' Contributions}

Cang Wang and Xiaoyi Ma contributed equally to this work.

\section{Acknowledgments}

This study was supported by the National Key R\&D Program of China (2018YFC0311106), the Priority Academic Program Development of Jiangsu Higher Education Institutions (PAPD), and the Research \& Practice Innovation Program of Jiangsu (SJCX19-2297 and ZD201918).

\section{References}

[1] A. Chatterjee, P. Bharadiya, and D. Hansora, "Layered double hydroxide based bionanocomposites," Applied Clay Science, vol. 177, pp. 19-36, 2019. 
[31] C. Baker-Austin, J. D. Oliver, M. Alam et al., “_Vibrio_spp. infections," Nature Reviews Disease Primers, vol. 4, no. 1, pp. 1-19, 2018.

[32] W. Peng, Y. Shi, G. F. Li et al., “_Tetraodon nigroviridis_ : a model of _Vibrio parahaemolyticus_infection," Fish \& Shellfish Immunology, vol. 56, pp. 388-396, 2016.

[33] X. Guo, C. Ji, X. Du, J. Ren, and Q. Zhang, “Comparison of gene expression responses of zebrafish larvae to _Vibrio parahaemolyticus_infection by static immersion and caudal vein microinjection," Aquaculture and Fisheries, vol. 6, no. 3, pp. 267-276, 2021.

[34] X. Zhang, X. Tang, N. T. Tran et al., "Innate immune responses and metabolic alterations of mud crab ( _Scylla paramamosain_ ) in response to _Vibrio parahaemolyticus_infection," Fish \& Shellfish Immunology, vol. 87, pp. 166-177, 2019.

[35] L. Zhang and K. Orth, "Virulence determinants for_Vibrio parahaemolyticus_ infection," Current Opinion in Microbiology, vol. 16, no. 1, pp. 70-77, 2013.

[36] Q. Cai and Y. Zhang, "Structure, function and regulation of the thermostable direct hemolysin (TDH) in pandemic _Vibrio parahaemolyticus_," Microbial Pathogenesis, vol. 123, pp. 242-245, 2018.

[37] P. Paria, H. J. Chakraborty, B. K. Behera, P. K. Das Mohapatra, and B. K. Das, "Computational characterization and molecular dynamics simulation of the thermostable direct hemolysinrelated hemolysin (TRH) amplified from Vibrio parahaemolyticus," Microbial Pathogenesis, vol. 127, pp. 172-182, 2018.

[38] J. W. Costerton, L. Montanaro, and C. R. Arciola, "Biofilm in implant infections: its production and regulation," International Journal of Artificial Organs, vol. 28, no. 11, pp. 10621068, 2005.

[39] X. Song, Y. Ma, J. Fu, A. Zhao, and Y. Zhao, "Effect of temperature on pathogenic and non-pathogenic Vibrio parahaemolyticus biofilm formation," Food Control, vol. 73, pp. 485-491, 2016.

[40] Y. Yin, P. Ni, D. Liu et al., "Bacteriophage potential against _Vibrio parahaemolyticus_ biofilms," Food Control, vol. 98, pp. 156-163, 2019.

[41] F. Fei, B. Liu, X. Gao, X. Wang, Y. Liu, and H. Bin, "Effects of supplemental ultraviolet light on growth, oxidative stress responses, and apoptosis-related gene expression of the shrimp _Litopenaeus vannamei_," Aquaculture, vol. 520, p. 735013, 2020.

[42] Ç. U. Pala and A. K. Toklucu, "Effects of UV-C light processing on some quality characteristics of grape juices," Food and Bioprocess Technology, vol. 6, no. 3, pp. 719-725, 2013.

[43] B. G. Petri, R. J. Watts, A. L. Teel, S. G. Huling, and R. A. Brown, "Fundamentals of ISCO using hydrogen peroxide," in In situ chemical oxidation for groundwater remediation, pp. 33-88, Springer, 2011.

[44] A. P. Fraise, J. Y. Maillard, and S. Sattar, Russell, Hugo \& Ayliffe's Principles and Practice of Disinfection, Preservation \& Sterilization, 2013, Blackwell Pub.

[45] S. H. Chang, "Gold(III) recovery from aqueous solutions by raw and modified chitosan: a review," Carbohydrate Polymers, vol. 256, no. 5, p. 117423, 2020.

[46] N. A. Chudasama and A. K. Siddhanta, "Facile synthesis of nano-sized agarose based amino acid-its $\mathrm{pH}$-dependent protein-like behavior and interactions with bovine serum albumin," Carbohydrate Research, vol. 417, pp. 57-65, 2015.
[47] S.-J. Ryu, H. Jung, J.-M. Oh, J.-K. Lee, and J.-H. Choy, "Layered double hydroxide as novel antibacterial drug delivery system," Journal of Physics and Chemistry of Solids, vol. 71, no. 4, pp. 685-688, 2010.

[48] F. Ahmed, S. M. Faisal, A. Ahmed, and Q. Husain, "Beta galactosidase mediated bio-enzymatically synthesized nano-gold with aggrandized cytotoxic potential against pathogenic bacteria and cancer cells," Journal of Photochemistry and Photobiology B: Biology, vol. 209, p. 111923, 2020. 